\title{
A Toxin from the Tangerine Pathotype of Alternaria alternata That Has Selective Toxicity to Japanese Pear*
}

\author{
Yasuo ITOH $^{* *}$, Keisuke KoHmoto**, Norihiro ShImomurA ${ }^{* *,}$, \\ Hiroshi OTANI**, Motoichiro Kodama** and Shinich NAKATSUKA ${ }^{* * *}$
}

\begin{abstract}
An isolate of Alternaria alternata from citrus was found to be pathogenic to both Japanese pear (cv. Nijisseiki) and Emperor mandarin. The fungus produced a toxin that is highly toxic to the pear and less toxic to the original host, Emperor mandarin. The toxin was isolated and was designated ACT-toxin IIb. ACT-toxin IIb caused vein necrosis and loss of electrolytes from leaves of $\mathrm{cv}$. Nijisseiki at concentrations more than $1 \times 10^{-7} \mathrm{M}$. The toxin caused vein necrosis at $4 \times 10^{-5} \mathrm{M}$, and increased losses of electrolytes from leaves of the citrus Emperor mandarin at $10^{-5} \mathrm{M}$. The toxin did not affect leaves of Japanese pear $\mathrm{cv}$. Chojuro and rough lemon at $10^{-4} \mathrm{M}$. Electron microscopy showed that ACT-toxin IIb caused invaginations of the plasma membrane in leaf cells of susceptible Japanese pear cv. Nijisseiki, but did not show such effect on resistant pear cv. Chojuro. These results indicate that the mode of action of ACT-toxin IIb is similar to that of $\mathrm{ACT}$-toxin Ib and AK-toxin (from the Japanese pear pathotype of $A$. alternata). ACT-toxin IIb also induced susceptibility in Japanese pear cv. Nijisseiki to a non-pathogenic isolate of $A$. alternata. The finding that the pathotype of $A$. alternata from citrus also has host-selective pathogenicity to certain Japanese pear indicates the danger of growing such susceptible pears near citrus-growing areas, and a potential problem from the introduction of the citrus pathogen into areas of Japanese pear cultivation.
\end{abstract}

(Received December 24, 1992)

Key words: Host-specific toxin, ACT-toxin I, ACT-toxin II, Japanese pear, mandarin, Alternaria alternata tangerine pathotypes.

\section{INTRODUCTION}

Two pathotypes of Alternaria alternata (Fr.) Keissler (formerly, distinct strains of $A$. citri Ellis and Pierce) cause brown spots on young leaves and immature fruits of citrus species ${ }^{8,18,19}$. One of these pathotypes is selectively pathogenic to Dancy tangerine and Emperor mandarin (Citrus reticulata), but has no obvious effect on rough lemon $(C \text {. jambhiri })^{4,18,19)}$. On germination, spores of this pathotype produce a toxin (ACT-toxin Ib) with the same host specificity as the fungus itself ${ }^{6)}$. Recently, the toxin was chemically characterized; it is an ester of epoxy-decatrienoic acid and $N$-acylvaline ${ }^{6,11}$. Kono et al. reported toxins (ACTG-toxins) which have selective toxicity on Emperor mandarin ${ }^{\text {") }}$, while the structures of these toxins were different from ACT-toxin Ib. The other pathotype is selectively pathogenic to rough lemon and Rangpur lime (C. limonia), but not to Dancy tangerine and Emperor

- This was supported in part by Research Grants Nos. 63440010, 02044099 and 02304019 from the Japanese Ministry of Education, Science and Culture, and by a special research grant (1989) from Tottori University.

** Laboratory of Plant Pathology, Faculty of Agriculture, Tottori University, Tottori 680, Japan 鳥取大学 農学部

*** Laboratory of Bioorganic Chemistry, Faculty of Agriculture, Gifu University, Gifu 501-11, Japan 枝卓大学 農学部

†'Present address : Tottori Mycological Institute, Tottori 689-11, Japan 現在：日本きのこセンター菌蓝研究所 
mandarin ${ }^{4,19)}$. The rough lemon pathotype also produces a toxin (ACR-toxin ${ }^{101}$ or ACRL-toxin ${ }^{11}$ ) with the same host specificity as the fungus.

These two pathotypes of $A$. alternata have not been found in Japan, although potential citrus hosts, such as cultivars Amanatsu, Iyo, and Kinokuni, have been cultivated for many years ${ }^{4)}$. Kohguchi $e t$ al..$^{3)}$ found in laboratory tests that the tangerine pathotype is also pathogenic to Japanese pear (Pyrus pyrifolia) $\mathrm{cv}$. Nijisseiki. The tangerine pathotype produces at least two host-specific toxins: ACT-toxin I (formerly known as ACT-toxin A) that affects susceptible citrus and ACT-toxin II (formerly, ACTtoxin $\mathrm{B}$ ) that is toxic to Japanese pear $\mathrm{cv}$. Nijisseiki $\mathrm{i}^{2}$. Unexpected pathogenicity of this pathotype can be explained by production of the major toxin (ACT-toxin Ib). Purified ACT-toxin Ib affected not only susceptible citrus, but also caused necrosis and induced infection by nonpathogenic $A$. alternata on leaves of Japanese pear cv. Nijisseiki, when the spores plus toxin $\left(1 \times 10^{-6} \mathrm{M}\right)$ were applied ${ }^{6}$. However, production of other possible toxins by the tangerine pathotype had not been studied. We herein report the isolation and characterization of biological activities of ACT-toxin IIb produced by an isolate of the tangerine pathotype of $A$. alternata. ACT-toxin IIb was selectively toxic to Japanese pear cv. Nijisseiki, but had little or no effect on susceptible citrus. Abstracts of the study were published ${ }^{2,3,5}$.

\section{MATERIALS AND METHODS}

Plants. Japanese pear cvs. Nijisseiki and Chojuro, Emperor mandarin and rough lemon were used for bioassaying phytotoxicity. These plants were grown in a greenhouse and young leaves were used. In addition, young leaves of many other cultivars of Japanese pear, were kindly provided from the Tottori Horticultural Experiment Station, and they were used for testing the host range of the tangerine pathotype and a toxin-sensitivity spectrum.

Fungi. Two isolates of $A$. alternata were used: a pathogenic isolate (AC-320) of the tangerine pathotype was kindly provided by Dr. J.O. Whiteside, (University of Florida, Citrus Research and Education Center, U.S.A.), and a nonpathogenic isolate (O-94). Spores were obtained from mycelial mats by the procedure described previously ${ }^{6}$. For toxin production, the isolate AC-320 was cultivated in still culture on a modified Richards' medium ${ }^{6}$ at $25^{\circ} \mathrm{C}$ for 24 days. Toxicity was determined by a leaf necrosis assay ${ }^{6}$.

Observation of infection behavior of nonpathogenic isolate. To test pathogenicity and infection behavior, spores $\left(5 \times 10^{5}\right.$ per $\left.\mathrm{ml}\right)$ of the nonpathogenic isolate $(0-94)$ were suspended in a dilute solution of ACT-toxin IIb $\left(1 \times 10^{-7} \mathrm{M}\right)$ and inoculated by spraying with an atomizer onto the lower surface of leaves. Control leaves were sprayed with deionized water containing spores at the same density. Fungal infection behavior was observed under a microscope ${ }^{6)}$.

High performance liquid chromatography (HPLC). Solutions containing toxin were subjected to analytical and preparative HPLC, using a Hitachi HPLC system equipped with a L-3000 photo diode array detector, L-6200 intelligent pump, and D-6000 data station. To analyze sample solutions, a Develosil ODS- 5 column $(4.6 \times 250 \mathrm{~mm})$ was used with a $\mu$-Bondapak $\mathrm{C}_{18}$ guard column (Waters Co. Ltd.). Preparative HPLC was with a Develosil ODS-7 column $(10 \times 250 \mathrm{~mm})$ with a Develosil ODS-15/30 guard column. Develosil ODS-gels were from Nomura Chemical Co. Ltd. Sample solutions were filtered with a $0.2 \mu \mathrm{m}$ Millipore filter and subjected to HPLC at room temperature. Detailed conditions for HPLC are given in RESULTS.

Electron microscopy. Electron microscope observations of cells were performed as described by Kohmoto et al. ${ }^{\text {s) }}$

\section{RESULTS}

\section{Isolation of ACT-toxin IIb}

ACT-toxin Ilb was isolated by the method similar to the isolation procedure previously described for ACT-toxin $\mathrm{Ib}^{6}$. The method is summarized in Fig. 1. The ethyl acetate extract of toxins from culture filtrate of the isolate AC-320 was subjected to droplet countercurrent chromatography (DCC) using a 


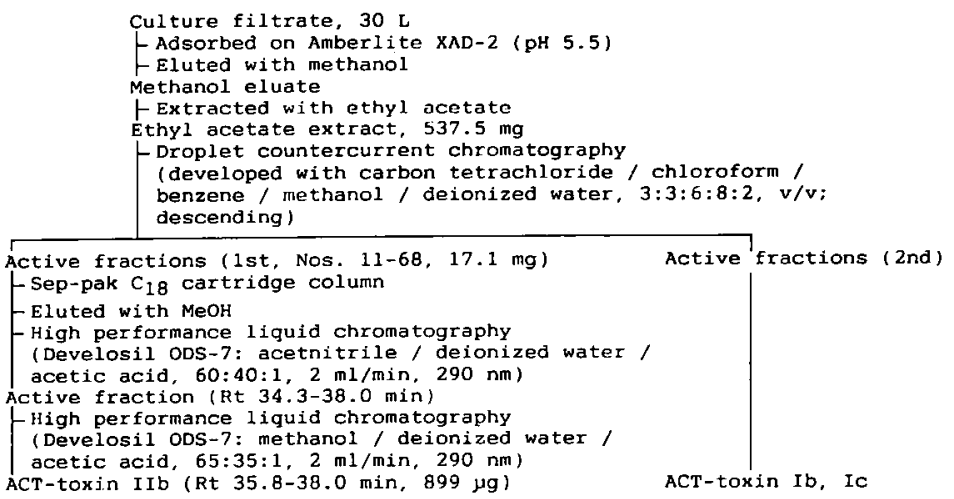

Fig. 1. Outline of the isolation procedures for ACT-toxin IIb from culture filtrates of the tangerine pathotype of $A$. alternata (isolate AC-320).

Tokyo Rikakikai model DCC-A instrument, and developed in descending mode : the solvent was carbon tetrachloride/chloroform/benzene/methanol/deionized water $(3: 3: 6: 8: 2, \mathrm{v} / \mathrm{v} / \mathrm{v} / \mathrm{v} / \mathrm{v})$. Two hundred fractions (each containing $10 \mathrm{ml}$ ) were collected. Leaf necrosis assays showed two groups of active fractions. The first active fractions (Nos. 11 to 68) were more toxic to Japanese pear cv. Nijisseiki than they were to Emperor mandarin. The second group of active fractions (Nos. 69 to 126) was highly toxic to Emperor mandarin and slightly toxic to Japanese pear cv. Nijisseiki. Based on TLC analysis (data not shown) and bioassay, the first fractions were judged to contain ACT-toxin II and the second to contain ACT-toxin $I^{6}$. The first fractions were pooled and evaporated. The residue was applied to Sep-pak $C_{18}$ cartridge column and then subjected to preparative HPLC on a Develosil ODS-7 column using acetonitrile/deionized water/acetic acid $(60: 40: 1, \mathrm{v} / \mathrm{v} / \mathrm{v})$ as a mobile phase, at a flow rate of 2 $\mathrm{ml} / \mathrm{min}$. Absorbance of the effluents was monitored at $290 \mathrm{~nm}$. One peak fraction (Rt 34.3-38.3 min) was highly toxic to Japanese pear cv. Nijisseiki. This fraction was evaporated and further subjected to preparative HPLC, using methanol/deionized water/acetic acid $(65: 35: 1, \mathrm{v} / \mathrm{v} / \mathrm{v})$, at a flow rate of $2 \mathrm{ml} /$ min. A peak fraction (Rt 35.8-38.0 min) was collected and subjected to analytic HPLC. This preparation moved as a single peak and was highly toxic to pear $\mathrm{cv}$. Nijisseiki, slightly toxic to Emperor mandarin, and not toxic to pear cv. Chojuro and rough lemon.

Comparative susceptibility and toxin sensitivity of Japanese pear cultivars to the tangerine pathotype of A. alternata

Leaves of 35 cultivars of Japanese pear were inoculated by spraying a spore suspension $\left(1 \times 10^{6}\right.$ spores per $\mathrm{ml}$ ) of the pathogenic isolate (AC-320) with an atomizer. Ten cultivars, including cv. Nijisseiki, proved to be susceptible to the tangerine pathotype of $A$. alternata. The remaining 25 cultivars were resistant (Table 1). Sensitivity of the cultivars to ACT-toxin Ib and Ilb was tested by the leaf necrosis assay method. ACT-toxin $\mathrm{Ib}$ was used at $1 \times 10^{-5}$ and $1 \times 10^{-4} \mathrm{M}$, and ACT-toxin IIb was used at $1 \times 10^{-6}$ and $1 \times 10^{-5} \mathrm{M}$. Dilution end points of toxicity of these toxins on cv. Nijisseiki were $1 \times$ $10^{-6} \mathrm{M}$ and $1 \times 10^{-7} \mathrm{M}$, respectively. ACT-toxins $\mathrm{Ib}$ and IIb at each concentration caused black vein necrosis on leaves of the ten cultivars that were susceptible to the pathogen. The toxins caused no necrosis on the 25 cultivars that were resistant to the pathogen even with the higher concentrations examined. Thus, among 35 cultivars, the spectrum of sensitivity to ACT-toxins completely coincides with that of the disease susceptibility.

\section{Biological activities of ACT-toxin IIb}

A dose-response study revealed that ACT-toxin IIb induced black vein necrosis on leaves of Japanese pear $\mathrm{cv}$. Nijisseiki at concentrations more than $1 \times 10^{-7} \mathrm{M}$. This toxin also caused brown vein necrosis on leaves of Emperor mandarin at a concentration of $4 \times 10^{-5} \mathrm{M}$ (data not shown in Fig. 2.). ACT-toxin Ilb did not cause necrosis on leaves of resistant plants (rough lemon and Japanese pear cv. 
Table 1. The correlation between susceptibility of Japanese pear cultivars to the tangerine pathotype of Alternaria altemata and sensitivity to its toxins (ACT-toxin Ib and IIb)

\begin{tabular}{|c|c|c|c|}
\hline \multirow{2}{*}{ Cultivar } & \multirow{2}{*}{ Inoculation ${ }^{\mathrm{a}}$} & \multicolumn{2}{|c|}{ Treatment with ACT-toxins ${ }^{b)}$} \\
\hline & & $\mathrm{Ib}^{\mathrm{c})}$ & IIb \\
\hline Chojuro & - & - & - \\
\hline Doitsu & + & + & + \\
\hline Gion & - & - & - \\
\hline Hakata-ao & + & + & + \\
\hline Hakuro & + & + & + \\
\hline Hokkai-wase & - & - & - \\
\hline Hosui & - & - & - \\
\hline Ichihara-wase & - & - & - \\
\hline Imamura-aki & - & - & - \\
\hline Ishii-wase & - & - & - \\
\hline Kikusui & - & - & - \\
\hline Kimizuka-wase & + & + & + \\
\hline Kogetsu & + & + & + \\
\hline Kosui & - & - & - \\
\hline Kozo & - & - & - \\
\hline Kumoi & - & - & - \\
\hline Meigetsu & + & + & + \\
\hline Niitaka & - & - & - \\
\hline Nijisseiki & + & + & + \\
\hline Okusankichi & - & - & - \\
\hline Osa-nijisseiki & + & + & + \\
\hline Seigyoku & - & - & - \\
\hline Seiryu & - & - & - \\
\hline Shinchu & - & - & - \\
\hline Shinko & - & - & - \\
\hline Shinseiki & - & - & - \\
\hline Shinsui & + & + & + \\
\hline Shirayuki & - & - & - \\
\hline Suisei & - & - & - \\
\hline Suisyu & - & - & - \\
\hline Taihaku & - & - & - \\
\hline Taiheiyo & - & - & - \\
\hline Yakumo & - & - & - \\
\hline Wase-aka & - & - & - \\
\hline Wase-nijisseiki & + & + & + \\
\hline
\end{tabular}

a) The reactions resulting from spore inoculation $\left(10^{6}\right.$ spores $\left./ \mathrm{ml}\right)$ with an atomizer were evaluated as + (lesions formed) or -(no lesions).

b) Two concentrations of ACT-toxin Ib $\left(10^{-5} \mathrm{M}\right.$ and $\left.10^{-4} \mathrm{M}\right)$ and ACT -toxin IIb $\left(10^{-6} \mathrm{M}\right.$ and $\left.10^{-5} \mathrm{M}\right)$ were used. The reactions were evaluated as +(necrosis was induced from a low concentration of each toxin) or -(no necrosis even at a high concentration of each toxin).

c) ACT-toxin Ib was obtained by the methods described by Kohmoto et al. ${ }^{6)}$

Chojuro) even at $1 \times 10^{-4} \mathrm{M}$. Furthermore, ACT-toxin IIb also caused a rapid increase in loss of electrolytes from leaf disks of the susceptible pear (cv. Nijisseiki) at concentrations more than $2 \times 10^{-7}$ M. Emperor mandarin was affected by ACT-toxin IIb at $1 \times 10^{-5} \mathrm{M}$ with a $15 \%$ increase in electrolyte loss as compared to the control (Fig. 2B). The toxin at $1 \times 10^{-5} \mathrm{M}$ did not affect loss of electrolytes from leaf disks of cv. Chojuro and rough lemon.

Ultrastructural changes in toxin-treated leaves

Vein necrosis was visible on leaves of susceptible Japanese pear (cv. Nijisseiki) $12 \mathrm{hr}$ after treatment with drops $(40 \mu 1)$ of ACT-toxin IIb solution at a concentration of $2 \times 10^{-7} \mathrm{M}$. Since the toxic effect was first visible on the leaf veins, and later extended to neighboring mesophyll cells, further observa- 

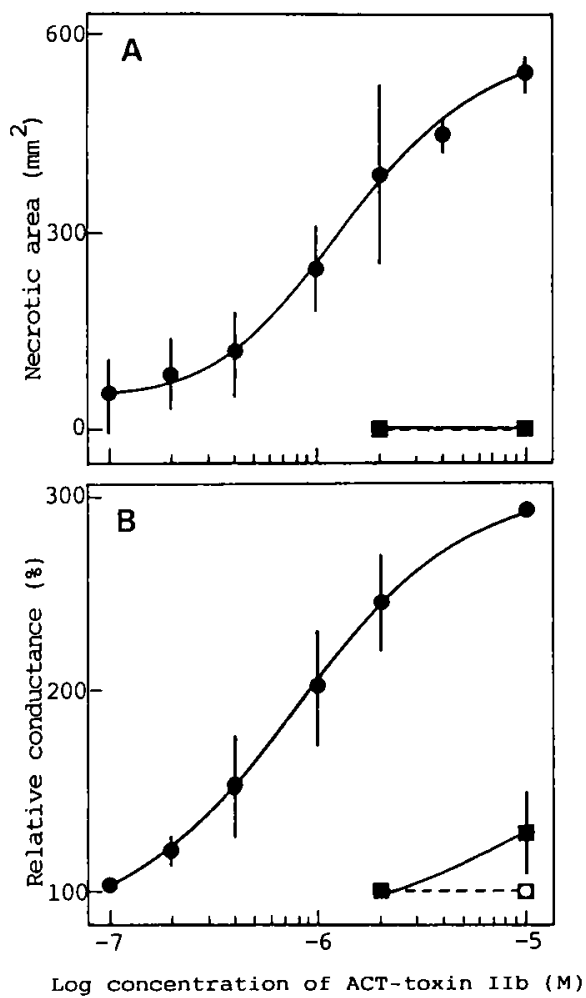

Fig. 2. Effect of ACT-toxin IIb on (A) development of vein necrosis in leaf tissues and (B) losses of electrolytes from leaf disks. Drops $(40 \mu 1)$ of toxin solutions were placed on leaves of Japanese pear cv. Nijisseiki (๑), cv. Chojuro (O), Emperor mandarin ( $\square$ ), and rough lemon ( $\square$ ). Areas of vein necrosis were measured $48 \mathrm{hr}$ later. Electrolyte leakage was measured at hourly intervals, as described by Kohmoto et al ${ }^{6)}$ and is reported as a value of relative conductance for $6 \mathrm{hr}$ between toxin-treated leaves and deionized-water-treated leaves (control). The vertical bars represent the standard deviations from three experiments.

tions were focused on cells in three types of leaf tissues : vascular bundle sheaths, mesophyll adjacent to the bundle sheaths, and mesophyll remote from the bundle sheath.

The first toxin-induced ultrastructual changes appeared on plasmodesmata of leaf cells $3 \mathrm{hr}$ after exposure to toxin (Plate I). ACT-toxin IIb caused invaginations of the plasma membrane at plasmodesmata; cells at the invaginated sites had membranes, vesicles, and desmotubules that extended from plasmodesmata (Plate I-C and D.). Frequency of invagination at the plasmodesmata differed in the three types of tissues. At $6 \mathrm{hr}$ after toxin exposure, the frequencies of invaginations were as follows : $69 \%$ in the bundle sheath, $41 \%$ in mesophyll cells adjacent to the bundle sheath, and $17 \%$ in mesophyll cells remote from the bundle sheath (Table 2). The invagination frequency increased with time. However, no effects were evident in $6 \mathrm{hr}$ on chloroplasts, mitochondria, and vacuoles (Plate I-E.). No ultrastructural changes were observed in leaf cells of resistant Japanese pear cv. Chojuro or rough lemon treated with $4 \times 10^{-6} \mathrm{M}$ ACT-toxin IIb (Table 2 and Plate I-F.).

Effect of ACT-toxin IIb on infection by nonpathogenic A. alternata on susceptible and resistant leaves

Leaves of Japanese pear cv. Nijisseiki that were inoculated with nonpathogenic spores suspended in a dilute solution of ACT-toxin $\operatorname{Ib}\left(1 \times 10^{-7} \mathrm{M}\right)$ showed a significant increase in the number of infection 


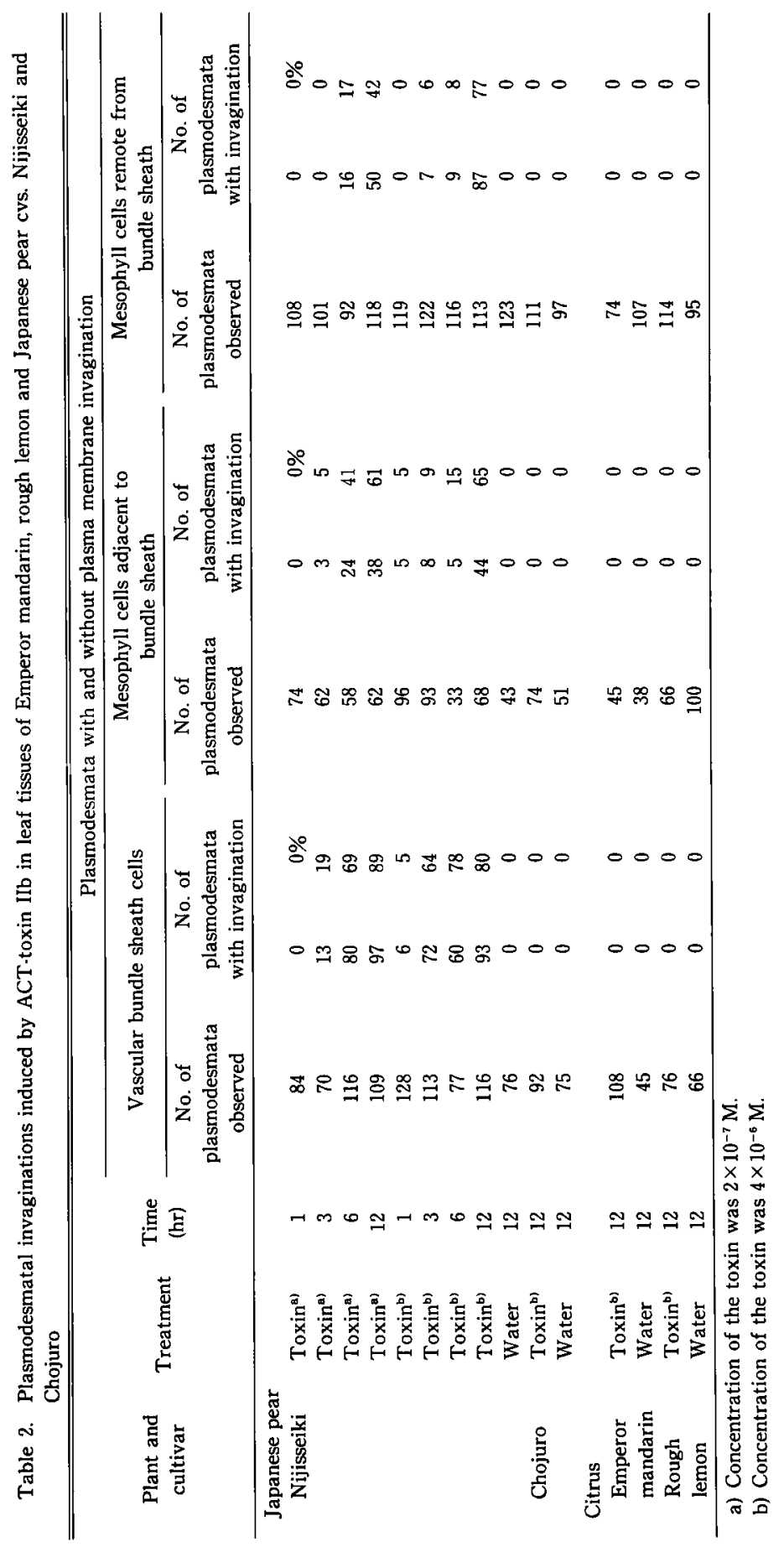


Table 3. Effect of ACT-toxin IIb on colonization of leaf tissues by a non-pathogenic isolate (O-94) of Alternaria alternata

\begin{tabular}{|c|c|c|c|c|c|}
\hline $\begin{array}{l}\text { Plant and } \\
\text { cultivar }^{\mathbf{a}}\end{array}$ & Inoculation & $\begin{array}{c}\text { Spore } \\
\text { germination } \\
(\%)\end{array}$ & $\begin{array}{l}\text { No. of } \\
\text { germ tubes } \\
\text { per spore }\end{array}$ & $\begin{array}{l}\text { Appressoria } \\
\text { per germ tube } \\
(\%)\end{array}$ & $\begin{array}{c}\text { Infection hyphae } \\
\text { per appressorium } \\
(\%)\end{array}$ \\
\hline \multicolumn{6}{|l|}{ Japanese pear } \\
\hline \multirow[t]{2}{*}{ Nijisseiki } & $0.94+$ Toxin $^{\text {b) }}$ & $92.3 \pm 1.7^{\mathrm{c})}$ & $1.2 \pm 0.1$ & $43.9 \pm 14.0$ & $30.4 \pm 8.2$ \\
\hline & 0.94 & $91.2 \pm 0.1$ & $1.3 \pm 0.1$ & $38.7 \pm 4.1$ & $6.9 \pm 3.5$ \\
\hline \multirow[t]{2}{*}{ Chojuro } & O-94+Toxin & $91.6 \pm 1.0$ & $1.4 \pm 0.1$ & $26.0 \pm 3.2$ & $11.4 \pm 0.4$ \\
\hline & 0.94 & $90.8 \pm 1.3$ & $1.3 \pm 0.1$ & $44.4 \pm 11.2$ & $11.9 \pm 5.1$ \\
\hline \multicolumn{6}{|l|}{ Citrus } \\
\hline Emperor & O-94+Toxin & $91.4 \pm 5.9$ & $1.3 \pm 0.1$ & $39.6 \pm 8.7$ & $14.1 \pm 3.1$ \\
\hline mandarin & $0-94$ & $91.1 \pm 2.2$ & $1.3 \pm 0.1$ & $39.1 \pm 9.2$ & $11.9 \pm 4.0$ \\
\hline Rough & O-94+Toxin & $90.9 \pm 4.1$ & $1.3 \pm 0.1$ & $43.1 \pm 3.4$ & $9.8 \pm 3.1$ \\
\hline lemon & 0.94 & $89.5 \pm 2.6$ & $1.2 \pm 0.1$ & $47.8 \pm 5.4$ & $10.8 \pm 3.0$ \\
\hline
\end{tabular}

a) Japanese pear cv. Nijisseiki is susceptible to both the Japanese pear pathotype and to this isolate of the tangerine pathotype of $A$. alternata. The Emperor mandarin is susceptible to the tangerine pathotype and rough lemon is resistant.

b) Spore suspension $\left(5 \times 10^{5}\right.$ spores $/ \mathrm{ml}$ ) was sprayed on the lower surface of leaves. $10^{-7} \mathrm{M}$ toxin was used.

c) Values are the means \pm S.D. from three experiments with observation of 100 spores.

hyphae produced. With the same treatment, leaves of Japanese pear cv. Chojuro, Emperor mandarin, and Rough lemon had no increase in the rate of formation of infection hyphae (Table 3). ACT-toxin IIb alone had no obvious effect on leaves of these Japanese pear and citrus types under the condition.

Release of ACT-toxin IIb during spore germination

The presence of ACT-toxin IIb in spore germination fluids was quantified by a method similar to that used for ACT-toxin $\mathrm{Ib}^{6)}$. The germination rate of spores of the pathogenic isolate AC- 320 reached about $80 \%$ in $6 \mathrm{hr}$ incubation. ACT-toxin IIb was first detected after $18 \mathrm{hr}$ of incubation; the amount was estimated at $0.024 \pm 0.016 \mathrm{pg}$ per germinated spore. After $24 \mathrm{hr}$, there was an average of $0.027 \pm 0.007 \mathrm{pg}$ of ACT-toxin Ilb per spore.

\section{DISCUSSION}

The major host-specific toxin (ACT-toxin Ib) of the tangerine pathotype of A. alternata was confirmed for the pathogenic isolate $\mathrm{AC}-320^{6}$ ). In addition, we have isolated from the identical cultures of the isolate AC-320 a new toxin that is highly active against Japanese pear cv. Nijisseiki, but is less toxic to susceptible tangerines. The toxin was designated ACT-toxin IIb, and characterized by Nakatsuka et al. as 8-(N-2",3",4"-trihydroxy-4",6"-dimethyl-6"-octenoylvalyl)-9,10-epoxy-9-methyl-decatrienoic acid (Fig. 3) ${ }^{12}$. It contains a central-cis decatrienoic acid moiety that is the same stereoisomer found in AK-toxins $\mathrm{I}$ and $\mathrm{II}^{16)}$ from the Japanese pear pathotype of $A$. alternata. It is also identical to the $\mathrm{b}$ type isomers of AF-toxins produced by the strawberry pathotype of $A$. altermata $^{14}$. The determination of structural details of ACT-toxin IIb will be published by Nakatsuka elsewhere.

ACT-toxin IIb is the 5"-deoxy derivative of ACT-toxin Ib (Fig. 4). This reduction, however, made ACT-toxin IIb ten-fold more toxic to pear cv. Nijisseiki but 2,000 fold less toxic to Emperor mandarin, as compared with ACT-toxin Ib. Hence, a hydroxy group at the $5^{\prime \prime}$-site appears to be important for selective toxicity to tangerines and related citrus. Reversed-phase HPLC analysis suggests a considerable difference in polarity between ACT-toxin Ib and IIb. ACT-toxin IIb had an approximately two times longer retention time on reversed-phase column than ACT-toxin Ib had (data not shown). This difference may result from a modification of the three-dimensional structure that also alters toxicity against sensitive plants. The modification may relate to an association with a putative binding site in sensitive cells.

Determination of the structure-activity relationships should contribute to the basis for a molecular 


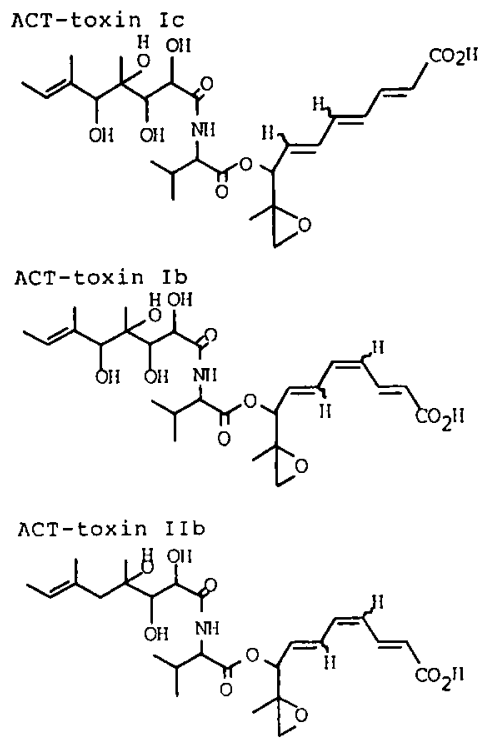

Fig. 3. Molecular structures of ACT-toxin Ib, Ic, and IIb.

study of toxic action against host cells. Comparative studies on HV-toxin derivatives, produced by Cochliobolus victoriae, showed that the latent aldehyde group of HV-toxin is bound covalently to a receptor protein in plant cells ${ }^{20 !}$. The case with host-specific toxins from $A$. alternata is more complex; fourteen related toxins contain the decatrienoic acid in their molecules and are toxic to Japanese pear cv. Nijisseiki ${ }^{6,14}$. These 14 toxins are AF-toxin I, II, III, (each contains three stereoisomers : a, b and c), AK-toxin I and II ; ACT-toxins Ib, Ic, and IIb. The relationship between structure and toxicity of the new ACT-toxin IIb to cv. Nijisseiki supports the hypothesis that an amide $\mathrm{NH}$ at the position 8 has an important role in specificity and toxicity of these decatrienoic acids ${ }^{14}$. However, the functional group that directly interacts with sites of action in cells has not been pinpointed to date.

ACT-toxin Ib and IIb were toxic only to Japanese pear cultivars that are susceptible to the tangerine pathotype of $A$. alternata (Table 1), in addition to its original host of citrus plants. Thus, they are clearly host-specific toxins. Besides, the tangerine pathotype had the same host range among Japanese pear cultivars as did the Japanese pear pathotype of $A$. alternata ${ }^{16}$. It is clear that ACT-toxin $\mathrm{Ib}$ and IIb can reproduce the same symptoms and have the same host-specificity as does the pathogen. The physiological effects of ACT-toxin Ib and IIb on pear cv. Nijisseiki were qualitatively indistinguishable in the three assay methods (induction of necrosis, increase in loss of electrolytes, and infection by nonpathogenic $A$. alternata $)^{6}$. The only difference was that ACT-toxin IIb required a 10 -fold lower concentration than a dose of ACT-toxin Ib for toxic effects, though ACT-toxin IIb was first detected by HPLC analysis from germinating spores $6 \mathrm{hr}$ later than ACT-toxin Ib was. The selective pathogenicity of the tangerine pathotype of $A$. alternata to Japanese pear, and to its original citrus host, could be based on the production of ACT-toxin IIb, besides ACT-toxin Ib.

There was a close relationship between necrosis and dysfunction of plasma membranes in toxintreated susceptible leaf tissues, as indicated by loss of electrolytes from the tissues. This was evident in a dose-response relationship with ACT-toxin IIb, where necrosis was correlated electrolyte losses (mainly, $\mathrm{K}^{+}$) (Fig. 2). In addition, electron microscopy of leaves of Japanese pear cv. Nijisseiki treated with ACT-toxin IIb showed that invaginations of the plasma membrane occurred at the plasmodesmata. The invaginations were first observed $3 \mathrm{hr}$ after exposure to the toxin; they increased rapidly during the following $3 \mathrm{hr}$. This alteration is similar to the ultrastructural changes that occur in cells of Japanese 
pear cv. Nijisseiki following exposure to AK-toxin ${ }^{17)}$ or ACT-toxin Ib $^{6}$. Finally, several metabolic inhibitors that counteracted on AK-toxin action ${ }^{15)}$, also suppressed action of ACT-toxin Ib and IIb (unpublished data). From these results, it is likely that the gene for susceptibility to the Japanese pear pathotype of $A$. alternata and to AK-toxins also confers Japanese pear's susceptibility and sensitivity to the tangerine pathotype of $A$. alternata and to ACT-toxins $\mathrm{Ib}$ and IIb. We postulate that the primary sites of action in Japanese pears are the same for these three toxins.

The host-pathogen interaction of the tangerine pathotype appears to be similar to that of the Japanese pear pathotype of $A$. alternata. This includes the events in initial colonization ${ }^{7}$. The indications are that the dysfunction of plasma membranes by ACT-toxin Ib and IIb is related to inhibition of general defense mechanisms in host tissues, which in turn allows for hyphal penetration and colonization of cells and tissues (Table 3 ). Thus, ACT-toxins $\mathrm{Ib}$ and $\mathrm{Ilb}$ are considered to be host recognition factors for the pathogen similar to the situation with other host-specific toxins from Alternaria and Bipolaris ${ }^{13,211}$.

Two facts indicate that the tangerine pathotype of $A$. alternata is a potential pathogen of Japanese pear cv. Nijisseiki. First, the tangerine pathotype produced on germination a toxin that selectively affects Japanese pear cv. Nijisseiki. Second, inoculation experiments with spores of the tangerine pathotype resulted in colonization of tissues and symptom development in pear cv. Nijisseiki. This emphasizes possible problems for plant quarantine. It is probable that the tangerine pathotype of $A$. alternata would become a problem if susceptible Japanese pears are introduced into citrus-growing areas of U.S.A. and Australia. Also the introduction of the tangerine pathotype into Japan may add to disease problems with both citrus and pears. This is the first example of the use of host-specific toxin to predict a new problem for agriculture. Studies of toxin-producing fungi obviously have unexpected implication.

The authors are greatly indebted to Dr. R.P. Scheffer, Michigan State University, for critical reading the manuscript and improving the text.

\section{Literature cited}

1. Gardner, J.M., Kono, Y., Tatum, J.H., Suzuki, Y. and Takeuchi, S. (1985). Plant pathotoxins from Alternaria citri: The major toxin specific for rough lemon plants. Phytochemistry 24 : 2861-2867.

2. Itoh, Y., Kohmoto, K., Otani, H., Kodama, M., Nishimura, S. and Nakatsuka, S. (1990). Isolation and biological activities of ACT-toxin IIb, produced by the tangerine pathotype of Alternaria alternata. Ann. Phytopath. Soc. Japan 56: 368 (Abstr. in Japanese).

3. Kohguchi, T., Kondoh, Y., Otani, H., Kohmoto, K. and Nishimura, S. (1985). Mode of action of ACT-toxins produced by Alternaria alternata tangerine pathotype on Japanese pear leaves. Ann. Phytopath. Soc. Japan. $51: 85$ (Abstr. in Japanese).

4. Kohmoto, K., Akimitsu, K. and Otani, H. (1991). Correlation of resistance and susceptibility of citrus to Alternaria alternata with sensitivity to host-specific toxins. Phytopathology $81: 719-722$.

5. Kohmoto, K., Itoh, Y., Kodama, M., Otani, H. and Nakatsuka, S. (1990). Isolation and structures of ACT-toxin I and II, host-specific toxins from the tangerine pathotype of Alternaria alternata. Phytopathology $80: 1067$ (Abstr.).

6. Kohmoto, K., Itoh, Y., Shimomura, N., Kondoh, Y., Otani, H., Kodama, M., Nishimura, S. and Nakatsuka, S. (1993). Isolation and biological activities of two host-specific toxins from the tangerine pathotype of Alternaria alternata. Phytopathology, 83 : 495-502.

7. Kohmoto, K., Otani, H., Kodama, M. and Nishimura, S. (1989). Host recognition: can accessibility to fungal invasion be induced by host-specific toxins without necessitating necrotic cell death? In Phytotoxins and Plant Pathogenesis. (A. Graniti, R.D. Durbin and A. Ballio, eds.). Springer-Verlag, Berlin \& Heidelberg. pp. 250-273.

8. Kohmoto, K., Scheffer, R.P. and Whiteside, J.O. (1979). Host-selective toxins from Altermaria citri. Phytopathology $69: 667-671$.

9. Kono, Y., Gardner, J.M. and Takeuchi, S. (1986). Structure of the host-selective toxins produced by a pathotype of Alternaria alternata causing brown spot disease of mandarins. Agric. Biol. Chem. 50: 801-804.

10. Nakatsuka, S., Goto, T., Nishimura, S. and Kohmoto, K. (1984). Host-Specific Phytotoxins. In: Natural Products and Biological Activities. (H. Imura, T. Goto, T. Murachi and T. Nakajima, eds.). University of 
Tokyo Press/Elsevier Sci. Publ., Tokyo/Amsterdam. pp. 11-18.

11. Nakatsuka, S., Goto, T., Itoh, Y., Kohmoto, K., Otani, H., Kodama, M. and Nishimura, S. (1989). Chemical studies on structures and host-specificities of ACT-toxins produced by Altermaria alternata tangerine pathotype causing citrus brown spot disease. Papers of 31th Symposium on the Chemistry of Natural Products (Nagoya) : 671-676 (in Japanese).

12. Nakatsuka, S., Itoh, Y., Kohmoto, K. and Nishimura, S. (1990). Structures of ACT-toxin Ib, c and IIb from the tangerine pathotype of Alternaria alternata and their host specificity. Ann. Phytopath. Soc. Japan 56 : 368 (Abstr. in Japanese).

13. Nishimura, S. and Kohmoto, K. (1983). Host-specific toxins and chemical structures from Alternaria species. Ann. Rev. Phytopathol. $21: 87-116$.

14. Nishimura, S. and Nakatsuka, S. (1989). Trends in host-selective toxin research in Japan. In Host-Specific Toxins: Recognition and Specificity Factors in Plant Disease. (K. Kohmoto and R.D. Durbin, eds.), Tottori Univ. Press, Tottori. pp. 19-31.

15. Otani, H., Haramoto, M., Kohmoto, K. and Nishimura, S. (1985). Two different phases in host cell damages induced by AK-toxin of Alternaria altemata Japanese pear pathotype. J. Fac. Agric. Tottori Univ. 20:817.

16. Otani, H., Kohmoto, K., Nishimura, S., Nakashima, T., Ueno, T. and Fukami, H. (1985). Biological activities of AK-toxins I and II, host-specific toxins from Alternaria altemata Japanese pear pathotype. Ann. Phytopath. Soc. Japan $51: 285-293$.

17. Park, P., Fukutomi, M., Akai, S. and Nishimura, S. (1976). Effect of the host-specific toxin from Alternaria kikuchiana on the ultrastructure of plasma membrane of cells in leaves of Japanese pear. Physiol. Plant Pathol. 9: 167-174.

18. Pegg, K.G. (1966). Studies of a strain of Altermaria citri Pierce, the causal organism of brown spot of Emperor mandarin. Queensl. J. Agric. Anim. Sci. 23 : 15-28.

19. Whiteside, J.O. (1976). A newly recorded Alternalia-induced brown spot disease on Dancy tangerines in Florida. Plant Dis. Reptr. $60: 326-329$.

20. Wolpert, T.J. and Macko, V. (1989). Specific binding to a 100-kDa protein from oats. Proc. Natl. Acad. Sci. USA $86: 4092-4096$.

21. Yoder, O.C. and Scheffer, R.P. (1969). Role of toxin in early interactions of Helminthosporium victoriae with susceptible and resistant oat tissues. Phytopathology 59 : 1954-1959.

\section{和 文 摘 要}

伊藤靖夫・甲元啓介・霜村典宏・尾谷 浩・児玉基一朗・中塚進一：タンゼリンの brown spot 病菌の生産する二ホ ンナシに選択書性を示す靑素

タンゼリンの brown spot 病菌は日本で未発生であるにもかかわらず, 二十世紀など特定のニホンナシ品種に対しナ シ黒病菌と同様の病原性を示す。本病原菌は, 宿主特異的毒素 ACT-toxin Ib の他に, ニホンナシに活性を示す毒素 を培黄液および胞子発芽液に生産する。これを単離して ACT-toxin IIb と命名した。本毒素は二十世紀ナシ葉に対し $1 \times 10^{-7} \mathrm{M}$, 宿主のタンゼリンやマンダリン葉に対し $4 \times 10^{-\mathrm{s}} \mathrm{M}$ 以上て壊死を誘起するが, 非宿主カンキツ葉や長十郎 ナシ葉には $1 \times 10^{-4} \mathrm{M}$ でも作用しなかった。毒素処理二十世紀ナシ葉では秉解質の異常漏出と原形質膜の楩入現象が 見られた。非病原性アルタナリア胞子に微量の毒素を添加して噴蓩接種すると，二十世紀ナシ葉だけに感染が成立し た。これらのことから，ACT-toxin IIb も宿主特異的毒素の属性を有すると判断された。タンゼリンの brown spot 病 菌はニホンナシにとって潜在的病原菌であり，植物検疫上重要であると考えられる。 


\section{Explanation of Plate}

\section{Plate I}

Electron micrographs of Japanese pear and citrus leaf tissues treated with ACT-toxin IIb and with deionized water. Ultrastructure of vascular bundle sheath cells of the susceptible Japanese pear leaf (cv. Nijisseiki) treated with (A) deionized water for $12 \mathrm{hr}(\times 6,100)$ and (B) $2 \times 10^{-7} \mathrm{M} \mathrm{ACT}$-toxin IIb for $6 \mathrm{hr}$. The toxin treated cells show many invaginations of plasma membrane (arrows) $(\times 6,100)$.

C. Invagination of plasma membranes in the susceptible Japanese pear leaf (cv. Nijisseiki) treated with $2 \times$ $10^{-7} \mathrm{M}$ ACT-toxin IIb for $6 \mathrm{hr}$. Invaginated portions, extended desmotubules (ED), tubular structure (TS), vesicles (V), and membrane structure (MS) were found $(\times 12,800)$.

D. Typical plasma membrane invagination in the susceptible Japanese pear leaf (cv. Nijisseiki) treated with $2 \times 10^{-7} \mathrm{M}$ ACT-toxin IIb for $6 \mathrm{hr}$. The space between invaginated plasma membrane and cell wall included densely stained membrane structure, vesicles and tubular structure $(\times 36,700)$.

E. Mesophyll cells of the susceptible Japanese pear leaf (cv. Nijisseiki) treated with $2 \times 10^{-7} \mathrm{M}$ ACT-toxin Ilb for $6 \mathrm{hr}$; there are invaginations of plasma membrane. No structural changes of chloroplasts (CHL), mitochondria $(\mathrm{M})$, and vacuoles $(\mathrm{VA})$ were observed $(\times 9,100)$.

F. Vascular bundle sheath cells of the resistant Japanese pear (cv. Chojuro) treated with $4 \times 10^{-6} \mathrm{M}$ ACT-toxin IIb for $12 \mathrm{hr}$; there are no ultrastructural changes $(\times 6,100)$. 


\section{Plate I}
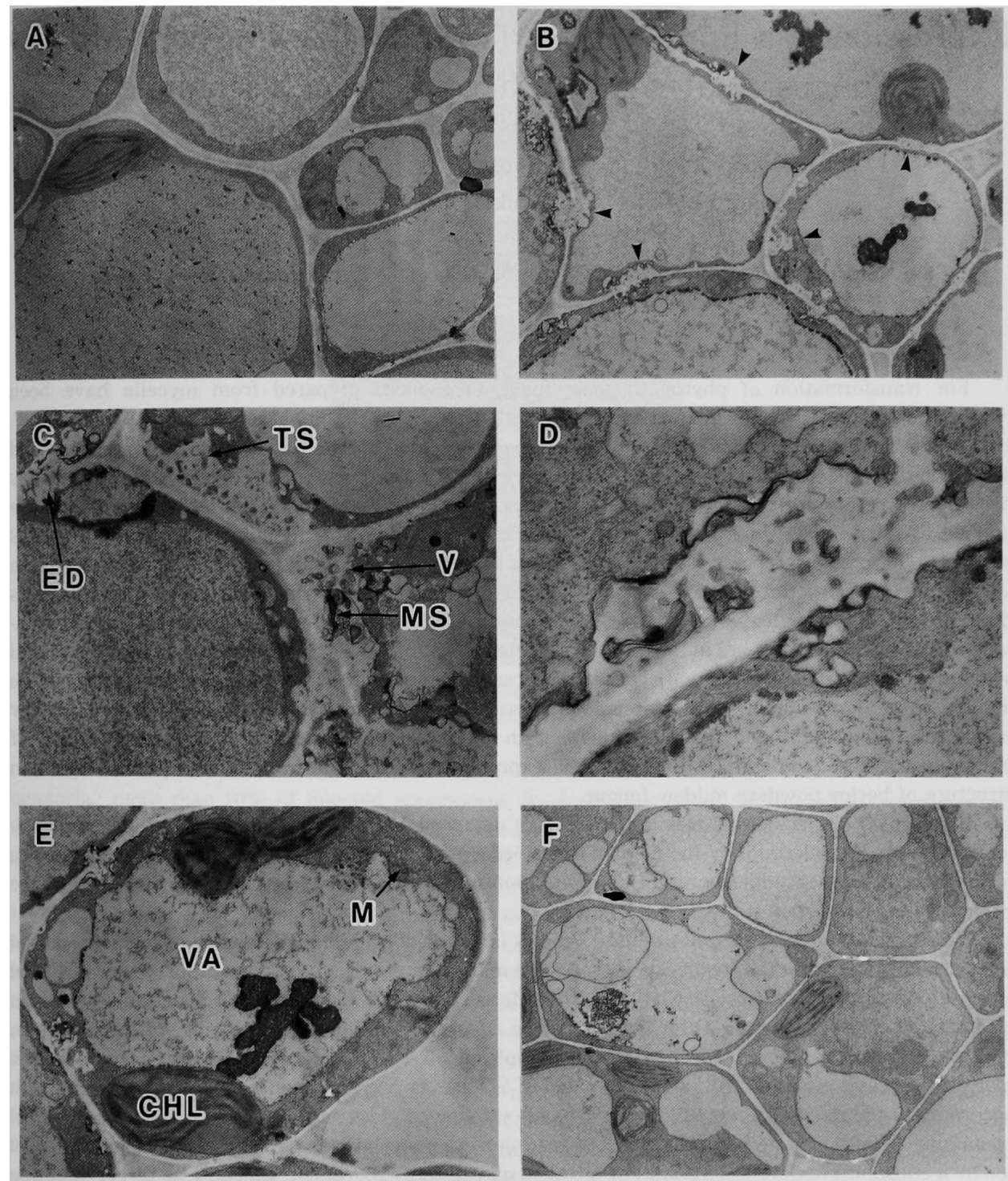